\title{
APLIKASI PERHITUNGAN PEMBIASAN DC PADA TRANSISTOR DWI KUTUB NPN DENGAN VISUAL BASIC 6.0
}

\section{VISUAL BASIC 6.0 APPLICATION FOR DC BIAS CALCULATION ON NPN-TYPE BIPOLAR JUNCTION TRANSISTOR}

\author{
${ }^{1)}$ Arief Hendra Saptadi, ${ }^{2}$ Eka Wahyudi, ${ }^{3)}$ Chandra AP Simorangkir \\ ${ }^{1,2,3)}$ Akademi Teknik Telekomunikasi Sandhy Putra Purwokerto
}

\begin{abstract}
7) ABSTRAKSI
Transistor dwi kutub (Bipolar Junction Transistor) adalah salah satu komponen semikonduktor yang sering digunakan dalam rangkaian penguat (amplifier). Untuk menjaga agar komponen ini dapat bekerja di dalam titik operasinya (operating point), maka diperlukan rangkaian pembiasan dengan pengaturan tertentu, yaitu Bias Basis, Bias Bagi Tegangan, Bias Kolektor dan Bias Emitter. Perancangan rangkaian tersebut lazimnya menggunakan perhitungan manual sesuai teori dengan bantuan alat hitung (kalkulator). Proses perancangan ini membutuhkan waktu yang relatif lama dan sangat rentan terjadi kesalahan prosedur perhitungan.

Tujuan dari penelitian ini adalah merancang perangkat lunak perhitungan rangkaian pembiasan transistor dwi kutub dengan Visual Basic 6. Proses perancangan meliputi pembuatan form, pembuatan basis data (database), penulisan kode sumber (coding), desain laporan (report) dan kompilasi. Dari hasil uji coba diketahui bahwa tingkat kesalahan (error) untuk perhitungan seluruh parameter dari 4 jenis rangkaian pembiasan adalah $1,18 \%$, sehingga disimpulkan layak digunakan. Hasil perhitungan juga dapat disajikan secara visual dalam rangkaian. Ditinjau dari sifat perangkat lunak ini sebagai aplikasi komputer, maka terdapat kelemahan dari sisi kepraktisan penggunaan, meski proses perhitungan dapat dilakukan relatif cepat. Selain itu, aplikasi ini masih memerlukan perbaikan dalam menu bantuan (help menu), penggunaan satuan dan faktor pengali.
\end{abstract}

Kata kunci: Transistor, Rangkaian Pembiasan, Titik Operasi, dan Visual Basic 6

\section{8) ABSTRACT}

Bipolar Junction Transistor is one of semiconductor components which is frequently used in amplifiers. To maintain this component in its operating point, it required biasing circuits with certain configurations, i.e. Fixed Bias, Voltage Divider Bias, Collector Bias and Emitter Bias. The design of the circuit usually utilized manual calculation based on theoretical approach, assisted with calculation instrument (i.e. handheld calculator). The design process was time-consuming and was prone to errors in calculation procedures.

The purpose of this research is to design Visual Basic 6 application for DC bias calculation on Bipolar Junction Transistors. The software design consisted of form design, database creation, coding, report design, compilation, testing and debugging. From the test results, it could be concluded that the average error on all parameters of four biasing circuits was $1,18 \%$; hence it was classified as feasible to use. The results of calculation could also be printed and displayed visually in the form of biasing circuits. Judging from the nature of this software as computer applications, there are weaknesses in terms of practicality of use, although the process of calculation could be done relatively quickly. In addition, this application still required improvements in the help menu, unit usage and multiplier factor.

Keywords: Transistor, Biasing Circuits, Operating Points and Visual Basic 6 


\section{1. PENDAHULUAN}

Transistor merupakan kependekan dari “Current-Transferring Resistor". Komponen ini pertama kali ditemukan oleh William Shockley, John Bardeen dan Walter Brattain ketika sedang bekerja dalam Laboratorium Telepon Bell pada tahun 1947.

Transistor pada umumnya digunakan pada rangkaian penguat (amplifier) dan menjadi blok dasar dari integrated circuits (IC). Pada saat ini transistor menjadi komponen inti di dalam microprosessor yang digunakan pada komputer pribadi (personal computer atau PC) dan berbagai perangkat komputasi lainnya.

Untuk dapat menghasilkan tegangan dan arus keluaran tertentu yang terjaga dengan baik, transistor perlu menggunakan sumber tegangan searah (direct current atau DC) yang kemudian dirangkai dengan tatanan rangkaian resistor tertentu, yang lazimnya disebut rangkaian pembiasan DC (DC biasing circuit). Komponenkomponen dalam rangkaian tersebut pada umumnya dihitung secara manual sesuai teori, namun berbagai tahapan perhitungan yang harus ditempuh memungkinkan terjadinya kesalahan.

Tujuan yang ingin dicapai dari penelitian ini yaitu membuat perangkat lunak untuk mempermudah perhitungan parameter-parameter dalam rangkaian pembiasan Transistor, yang dibangun dengan Visual Basic 6.

\subsection{Karakteristik \\ Transistor Dwi Kutub}

Transistor Dwi Kutub (Bipolar Junction Transistor) merupakan komponen semikonduktor tipe $\mathrm{p}$ dan $\mathrm{n}$ dengan struktur sebagaimana dua dioda yang disatukan dan memiliki jumlah kaki/pin sebanyak tiga, yaitu Emitter (E), Basis (B) dan Kolektor (C).

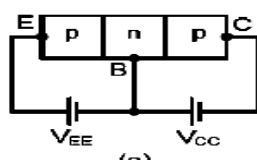

(a)

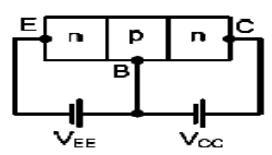

(b)
Gambar 1. Konstruksi Transistor (a) PNP (b) NPN

Terdapat dua jenis transistor yaitu NPN dan PNP dengan berbagai macam bentuk kemasan, antara lain selubung logam, keramik atau polyester.

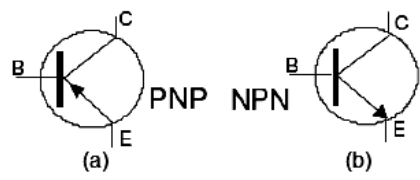

Gambar 2. Transistor (a) Simbol PNP (b) Simbol NPN (c) Bentuk Fisik

Pada jenis PNP, transistor beroperasi dengan diberikan bias pada bagian emitter-base dan collector-base. Bias maju pada terminal $\mathrm{V}_{\mathrm{EE}}$ menyebabkan sebagian besar arus pembawa mayoritas dari semikonduktor tipe $\mathrm{P}$ (yaitu hole), bergerak melewati daerah percabangan, masuk ke kolektor. Hanya sebagian kecil mengalir ke basis. Bias mundur pada terminal $\mathrm{V}_{\mathrm{CC}}$ menyebabkan sebagian kecil arus pembawa mayoritas dari semikonduktor tipe $\mathrm{N}$ (yaitu elektron) masuk ke percabangan kolektor dan basis.

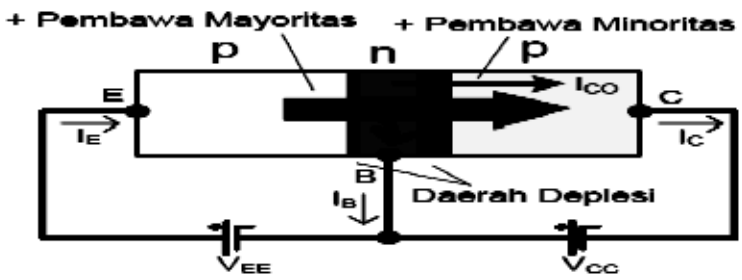

\section{Gambar 3. Operasi Transistor PNP}

Dengan memandang transistor sebagai sebuah titik, maka sesuai hukum arus Kirchoff: 


$$
I_{E}=I_{B}+I_{C}
$$

Perbandingan antara arus kolektor $\left(\mathrm{I}_{\mathrm{C}}\right)$ dan arus emitter $\left(\mathrm{I}_{\mathrm{E}}\right)$ disebut alpha DC $\left(\alpha_{\mathrm{DC}}\right)$ :

$\alpha_{D C}=\frac{I_{C}}{I_{E}}$

Besar penguatan arus antara bagian kolektor terhadap basis disebut beta $\mathrm{DC}\left(\beta_{\mathrm{DC}}\right)$ atau $\mathrm{h}_{\mathrm{FE}}$ :

$\beta_{D C}=h_{F E}=\frac{I_{C}}{I_{B}}$

Dengan mensubstitusikan (3) ke (1) maka diperoleh arus emitter:

$$
I_{E}=\left(\beta_{D C}+1\right) \cdot I_{B}
$$

\subsection{Konfigurasi Transistor NPN}

Transistor dapat beroperasi melalui tiga macam konfigurasi yaitu:

\section{a. Common Base (CB)}

Pada konfigurasi ini, kaki basis terhubung dengan ground dan berada diantara emitter dan kolektor. Percabangan emitter-base membentuk bagian input. Percabangan base-kolektor membentuk bagian output.

Konfigurasi ini sering digunakan sebagai penyangga arus (current buffer) atau penguat tegangan (voltage amplifier), khususnya pada rangkaian penguat berfrekuensi tinggi.

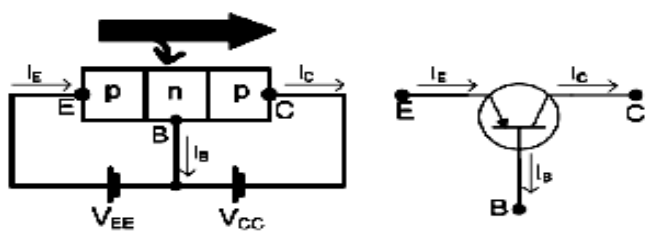

(a)

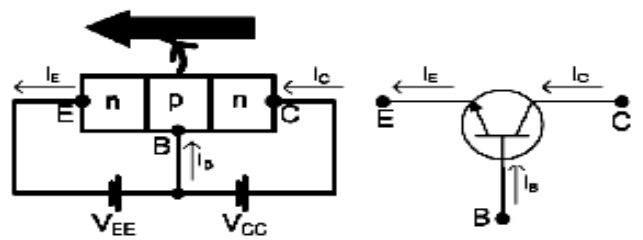

(b)

\section{b. Common Collector (CC)}

Pada konfigurasi ini, kaki kolektor terhubung dengan ground dan berada diantara basis dan emitter. Percabangan base-collector membentuk bagian input. Percabangan collectoremitter membentuk bagian output.

Konfigurasi ini sering digunakan sebagai penguat tegangan (voltage amplifier).

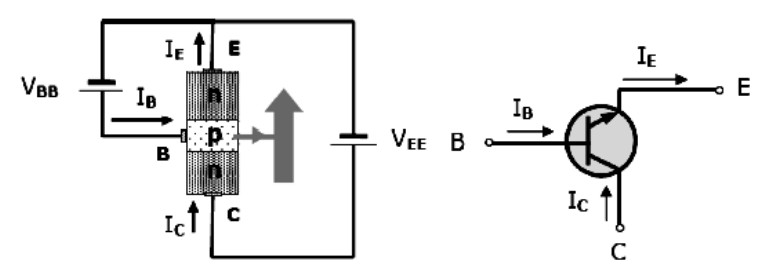

(a)

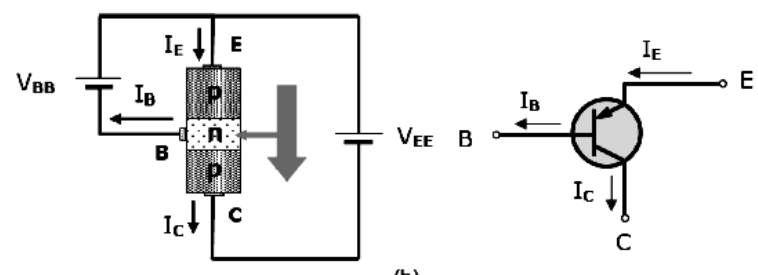

(b)

\section{Gambar 5. Common Collector (a) NPN (b)} PNP

\section{c. Common Emitter (CE)}

Pada konfigurasi ini, kaki emitter terhubung dengan ground dan berada diantara basis dan kolektor.
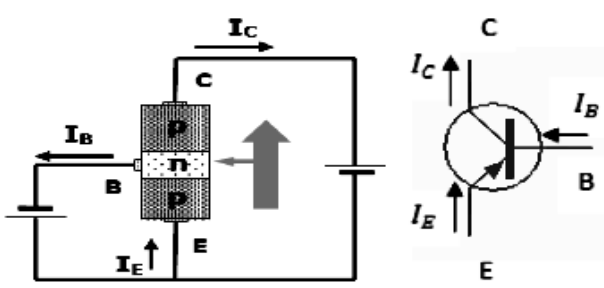

(a)
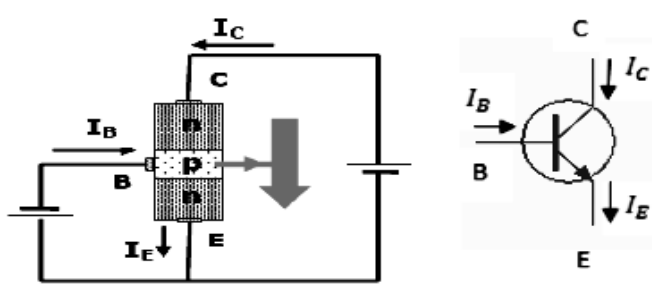

(b)

Gambar 6. Common Emitter (a) PNP (b) NPN

\section{Gambar 4. Common Base (a) PNP (b) NPN}


Percabangan base-emitter membentuk bagian input. Percabangan emitter-collector membentuk bagian output.

Konfigurasi ini sering digunakan sebagai penguat tegangan (voltage amplifier) dengan penguatan (gain) yang tinggi.

\subsection{Rangkaian Pembiasan}

Rangkaian pembiasan (biasing circuit) adalah rangkaian elektronika yang terdiri dari sumber tegangan searah (DC) dan susunan resistor tertentu dengan tujuan mengatur transistor pada suatu titik operasi (operating point).

Terdapat empat jenis rangkaian pembiasan:

\section{a. Bias Basis}

Rangkaian pembiasan ini terdiri dari tegangan DC yang terhubung ke kaki basis dan kolektor dari transistor $\left(\mathrm{V}_{\mathrm{CC}}\right)$, resistor basis $\left(\mathrm{R}_{\mathrm{B}}\right)$ dan resistor kolektor $\left(\mathrm{R}_{\mathrm{C}}\right)$.

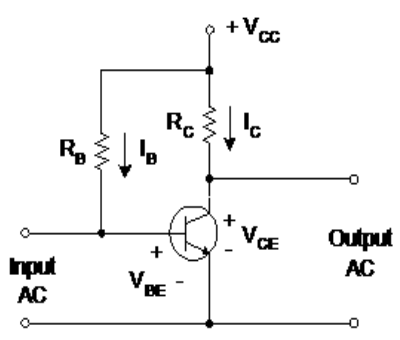

(a)

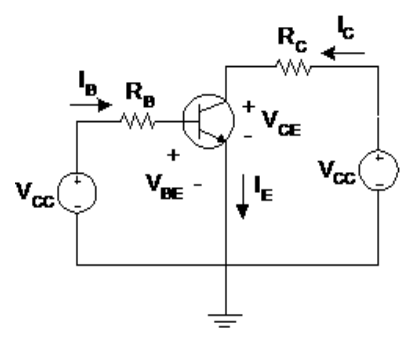

(b)
Gambar 7. Bias Basis (a) Rangkaian Dasar (b) Rangkaian Ekuivalen

Berdasarkan rangkaian ekuivalen di atas, dengan menggunakan hukum Kirchoff arus dan tegangan, maka nilai-nilai Q (Quiescent) pada titik operasi dapat dihitung:

$$
\begin{aligned}
I_{B Q} & =\frac{V_{C C}-V_{B E}}{R_{B}} \\
I_{C Q} & =I_{B Q} \cdot \beta_{D C}
\end{aligned}
$$

$$
V_{C E Q}=V_{C C}-I_{C Q} \cdot R_{C}
$$

Diagram garis beban dibuat dengan menentukan titik potong persamaan (7) terhadap sumbu vertikal dan horizontal.

$I_{C}=0 \rightarrow V_{C E}=V_{C C}$

$V_{C E}=0 \rightarrow I_{C}=\frac{V_{C C}}{R_{C}}$

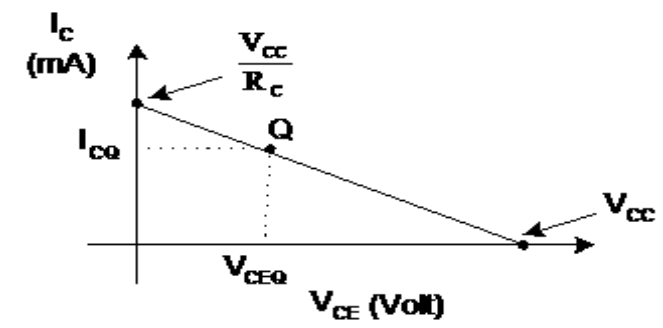

\section{Gambar 8. Garis Beban DC Bias Tetap}

\section{b. Bias Bagi Tegangan}

Rangkaian ini terdiri dari sumber tegangan $\mathrm{V}_{\mathrm{CC}}$ terhubung kaki kolektor dan basis, resistor kolektor $\left(\mathrm{R}_{\mathrm{C}}\right)$ dan resistor emitter $\left(\mathrm{R}_{\mathrm{E}}\right)$. Pada basis, tegangan tersebut terbagi oleh $\mathrm{R}_{1}$ dan $\mathrm{R}_{2}$ menjadi $\mathrm{V}_{\mathrm{BB}}$. Kombinasi paralel antara $\mathrm{R}_{1}$ dan $\mathrm{R}_{2}$ menjadi resistor basis $\left(\mathrm{R}_{\mathrm{B}}\right)$ :

$$
\begin{gathered}
R_{B}=\frac{R_{1} \cdot R_{2}}{R_{1}+R_{2}} \\
V_{B B}=\frac{R_{2}}{R_{1}+R_{2}}
\end{gathered}
$$

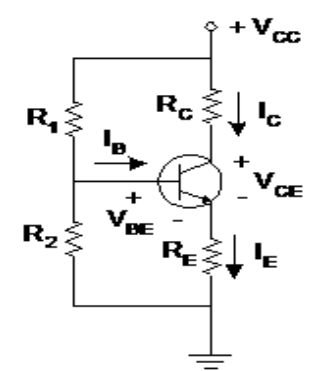

(a)

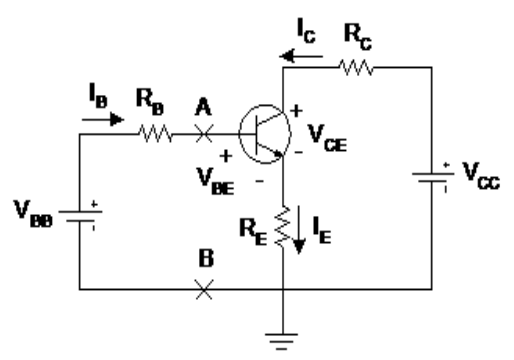

(b)
Gambar 9. Bias Bagi Tegangan (a) Rangkaian Dasar (b) Rangkaian Ekuivalen

Berdasarkan gambar 9b, pada titik operasi dapat dihitung: 
$I_{B Q}=\frac{V_{B B}-V_{B E}}{R_{B}+\left(\beta_{D C}+1\right) \cdot R_{E}}$

$V_{C E Q}=V_{C C}-I_{C Q} \cdot\left(R_{C}+R_{E}\right)$

dengan $\mathrm{I}_{\mathrm{CQ}}$ seperti pada persamaan (6).

Diagram garis beban dibuat dengan menentukan titik potong persamaan (13) terhadap sumbu vertikal dan horizontal.

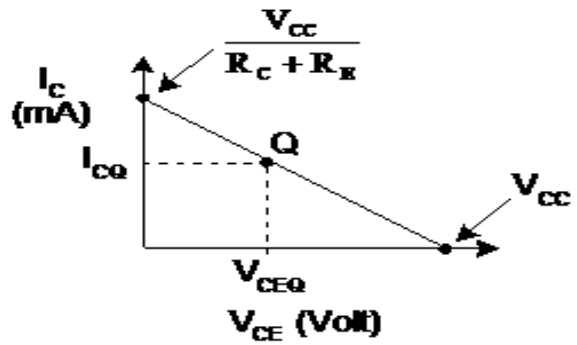

Gambar 10. Garis Beban DC Bias Bagi Tegangan

$V_{C E}=0 \rightarrow I_{C}=\frac{V_{C C}}{R_{C}+R_{E}}$

dengan kondisi $\mathrm{I}_{\mathrm{C}}=0$ seperti persamaan (8).

\section{c. Bias Kolektor}

Rangkaian pembiasan ini sangat mirip dengan bias basis, perbedaannya hanya terletak pada bagian resistor basis transistor yang diumpan balik ke kolektor tanpa melewati $\mathrm{V}_{\mathrm{CC}}$.

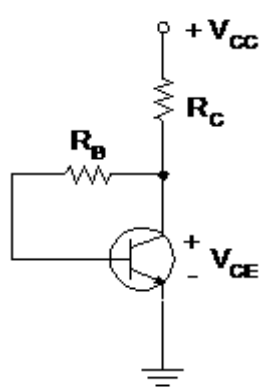

(a)

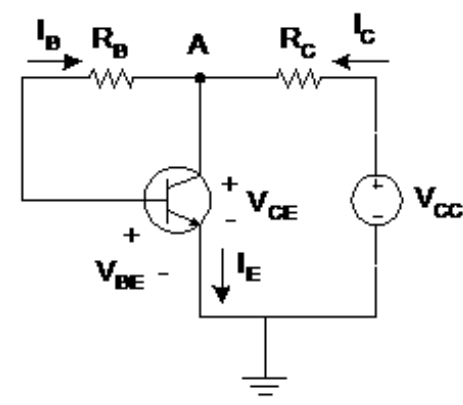

(b)
Gambar 11. Bias Kolektor (a) Rangkaian Dasar (b) Rangkaian Ekuivalen

Berdasarkan gambar 11b, maka nilai-nilai Q $I_{B Q}=\frac{V_{E E}-V_{B E}}{R_{B}+\left(\beta_{D C}+1\right) \cdot R_{E}}$

$V_{C E Q}=V_{C C}+V_{E E}-I_{C Q} \cdot\left(R_{C}+R_{E}\right)$

dengan $\mathrm{I}_{\mathrm{CQ}}$ seperti pada persamaan (6).

Diagram garis beban dibuat dengan menentukan titik potong persamaan (17) terhadap sumbu vertikal dan horizontal.

$I_{C}=0 \rightarrow V_{C E}=V_{C C}+V_{E E}$

$V_{C E}=0 \rightarrow I_{C}=\frac{V_{C C}+V_{E E}}{R_{C}+R_{E}}$

(Quiescent) pada titik operasi dapat dihitung:

$I_{B Q}=\frac{V_{C C}-V_{B E}}{R_{B}+\left(\beta_{D C}+1\right) \cdot R_{C}}$ 


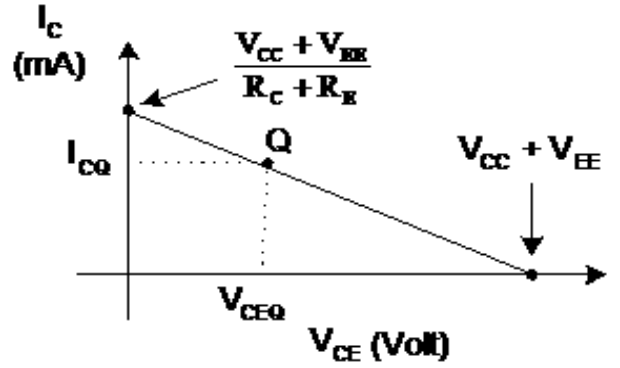

Gambar 13. Garis Beban DC Bias Emitter

\section{METODE PENELITIAN}

Dalam pembuatan perangkat ini, jenis metode penelitian yang digunakan adalah rekayasa perangkat lunak.

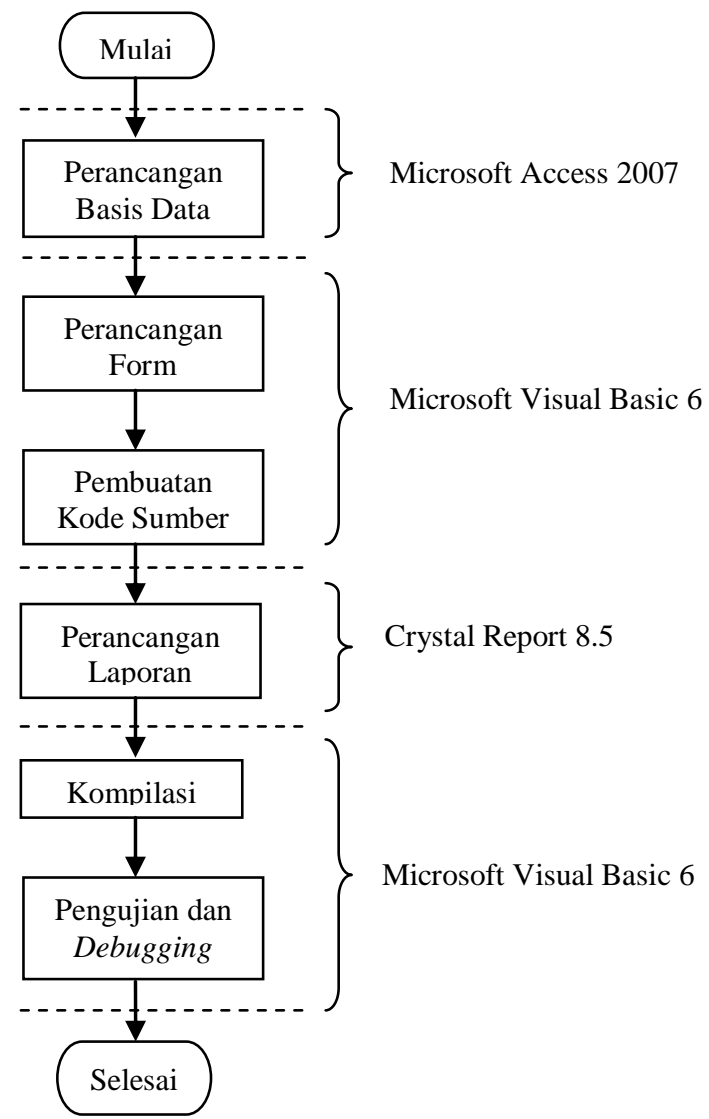

\section{Gambar 14. Tahap Perancangan Perangkat} Lunak

Metode ini bertujuan untuk membangun dan mengembangkan perangkat lunak melalui tahapan analisa, perancangan, implementasi, pengujian dan pemeliharaan. Adapun tahapan perancangannya seperti pada diagram alir dalam gambar 14.

\subsection{Perancangan Basis Data}

Basis data pada aplikasi ini difungsikan untuk menampung nilai-nilai sementara pada pembuatan laporan (report).

Basis data terdiri dari tabel sebanyak 4 buah yang berisi parameter-parameter yang terdapat dalam form aplikasi perhitungan. Pembuatan tabel dilakukan melalui Microsoft Access 2007.

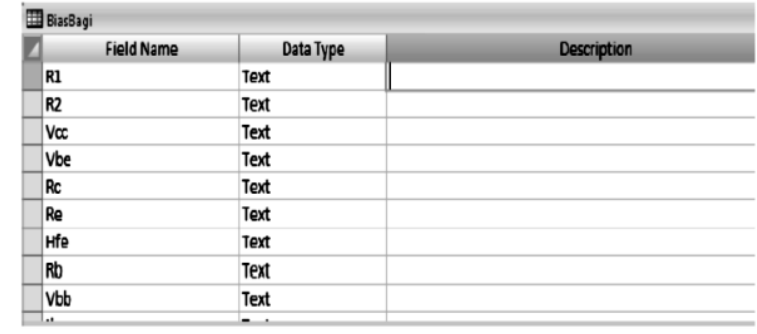

Gambar 15. Perancangan Tabel pada Microsoft Access 2007

Field yang dipergunakan dalam tiap tabel adalah sebagai berikut:

Tabel 1. Distribusi Field dalam 4 Tabel

\begin{tabular}{clcccc}
\hline \multirow{2}{*}{ No. } & \multirow{2}{*}{ Field } & $\begin{array}{c}\text { Tabel } \\
\text { bias_ } \\
\text { basis }\end{array}$ & $\begin{array}{c}\text { bias_ } \\
\text { bagi }\end{array}$ & $\begin{array}{c}\text { bias_ } \\
\text { kolektor }\end{array}$ & $\begin{array}{c}\text { bias_ } \\
\text { emitter }\end{array}$ \\
\hline 1. & RB & $\checkmark$ & $\checkmark$ & $\checkmark$ & $\checkmark$ \\
2. & R1 & & $\checkmark$ & & \\
3. & R2 & & $\checkmark$ & & \\
4. & RC & & $\checkmark$ & & $\checkmark$ \\
5. & RE & & $\checkmark$ & & $\checkmark$ \\
6. & VBE & $\checkmark$ & $\checkmark$ & $\checkmark$ & $\checkmark$ \\
7. & VBB & & $\checkmark$ & & \\
8. & VCC & $\checkmark$ & $\checkmark$ & $\checkmark$ & $\checkmark$ \\
9. & VEE & & & & $\checkmark$ \\
10. & IBQ & $\checkmark$ & $\checkmark$ & $\checkmark$ & $\checkmark$ \\
11. & ICQ & $\checkmark$ & $\checkmark$ & $\checkmark$ & $\checkmark$ \\
12. & VCEQ & $\checkmark$ & $\checkmark$ & $\checkmark$ & $\checkmark$ \\
13. & IC_max & $\checkmark$ & $\checkmark$ & $\checkmark$ & $\checkmark$ \\
14. & VCE_max & $\checkmark$ & $\checkmark$ & $\checkmark$ & $\checkmark$ \\
\hline
\end{tabular}

\subsection{Perancangan Form}

Pembuatan menu dan form aplikasi dilakukan melalui antarmuka Visual Basic 6, dengan susunan sebagai berikut: 


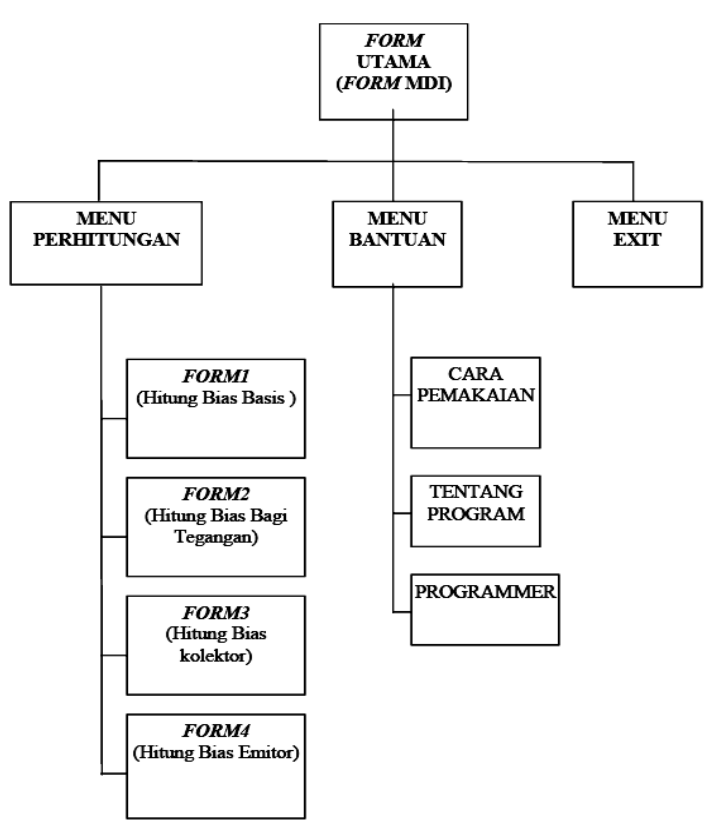

Gambar 16. Perancangan Menu dan Form Aplikasi

Menu utama aplikasi dibangun melalui fitur Menu Editor dengan tampilan seperti berikut:

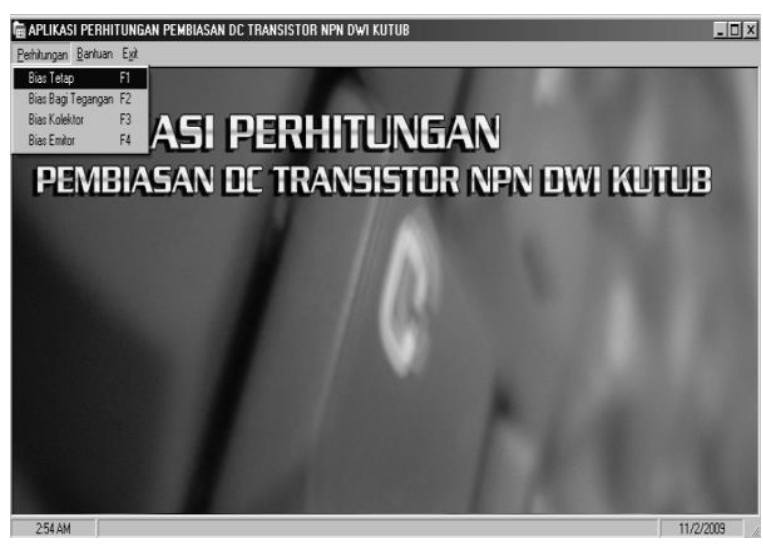

\section{Gambar 17. Tampilan Menu Utama Aplikasi}

Form perhitungan tiap rangkaian pembiasan dibangun melalui fitur Form Design, dengan tampilan sebagai berikut:

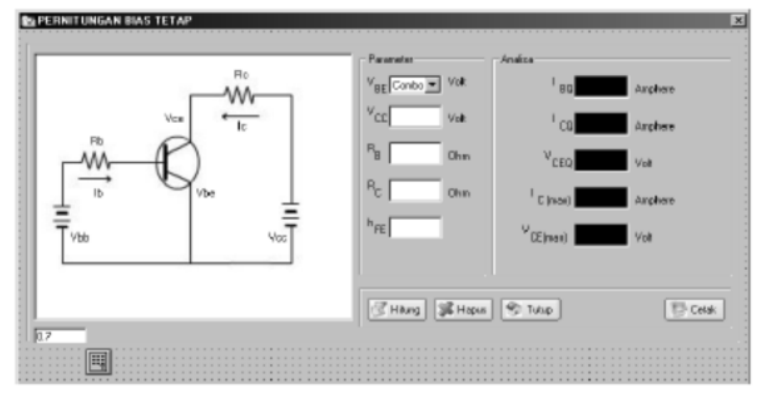

Gambar 18. Form Perhitungan Bias Basis

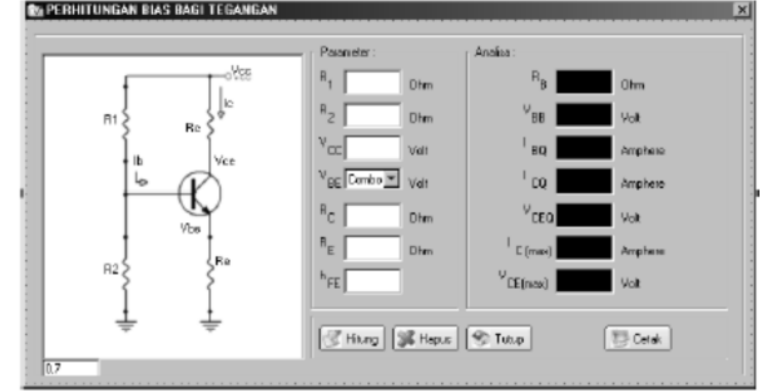

Gambar 19. Form Perhitungan Bias Bagi Tegangan

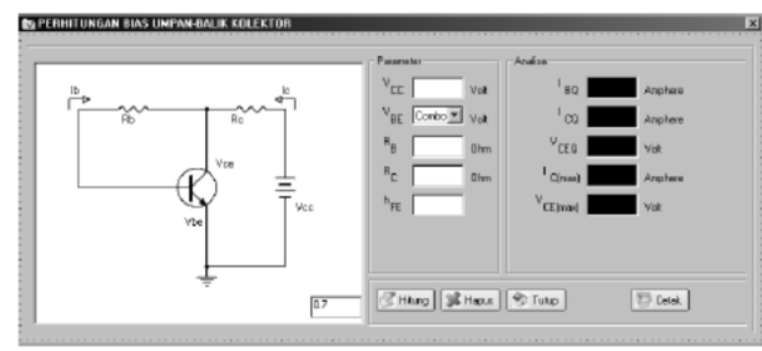

Gambar 20. Form Perhitungan Bias Kolektor

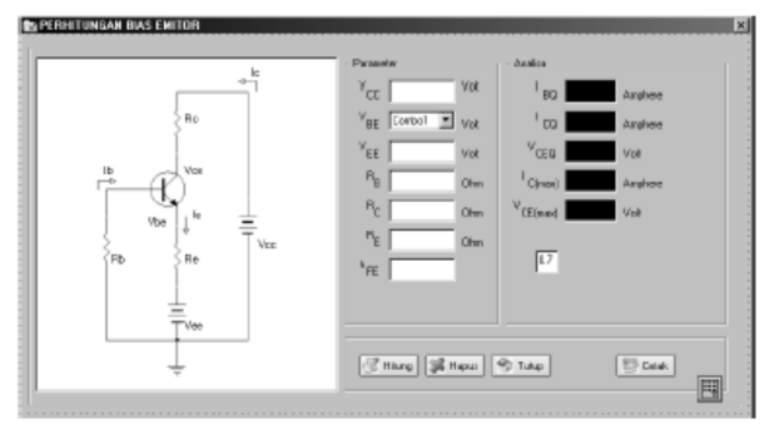

Gambar 21. Form Perhitungan Bias Emitter.

\subsection{Pembuatan Kode Sumber (Coding)}

Proses perhitungan rangkaian pembiasan dilakukan melalui kode program yang disematkan pada tombol Hitung dari form keempat rangkaian pembiasan.

Kode program untuk menghitung nilainilai titik operasi dan garis beban pada rangkaian:

\section{a. Bias Basis}

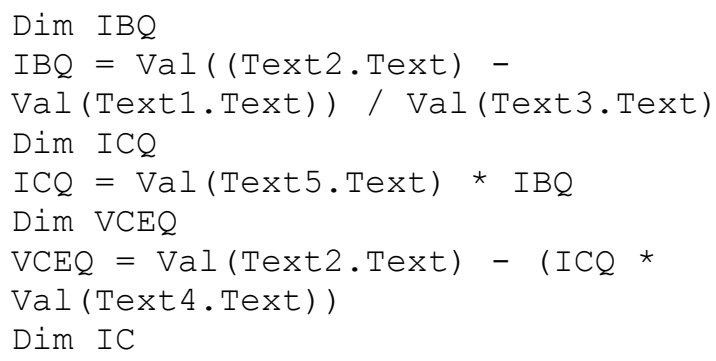




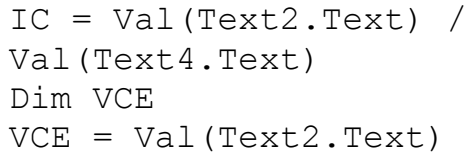

\section{b. Bias Bagi Tegangan}

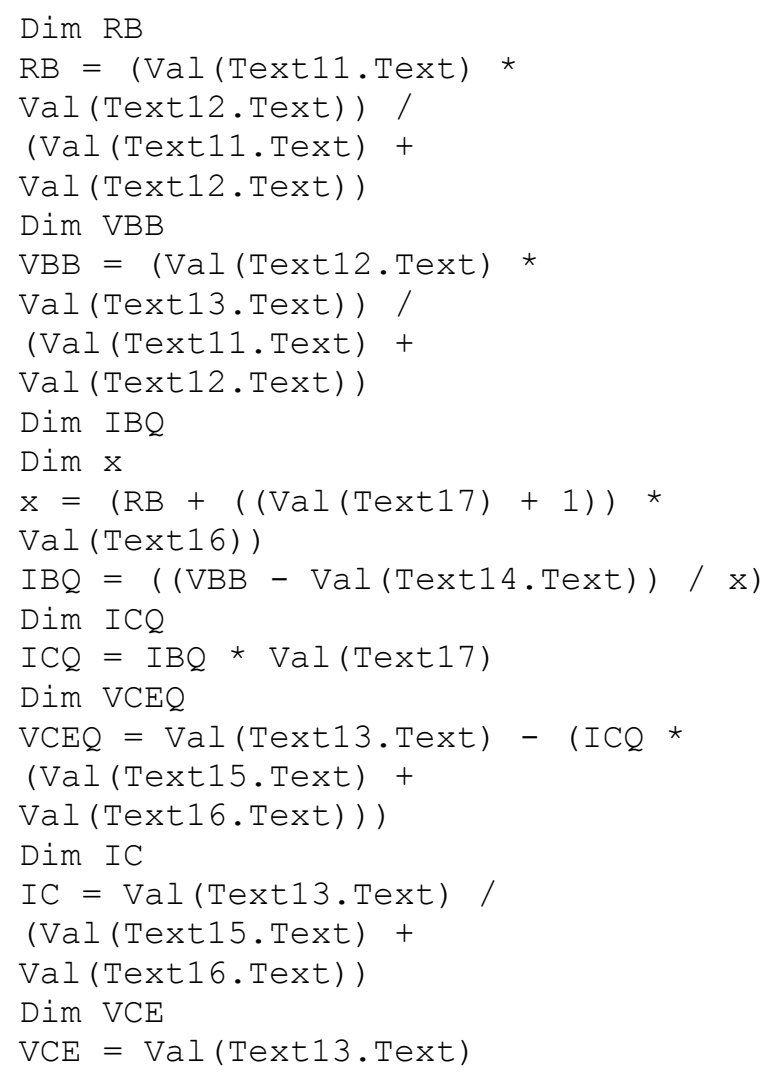

\section{c. Bias Kolektor}

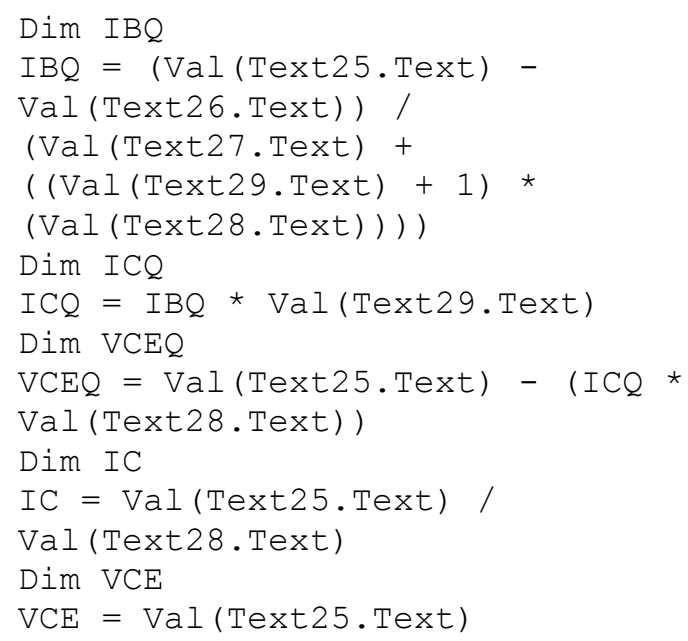

\section{d. Bias Emitter}

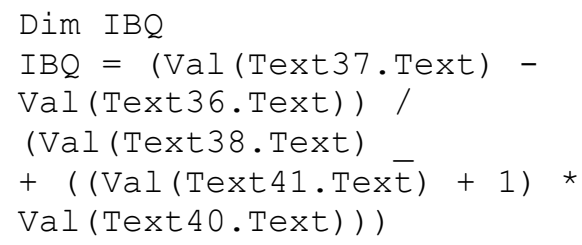

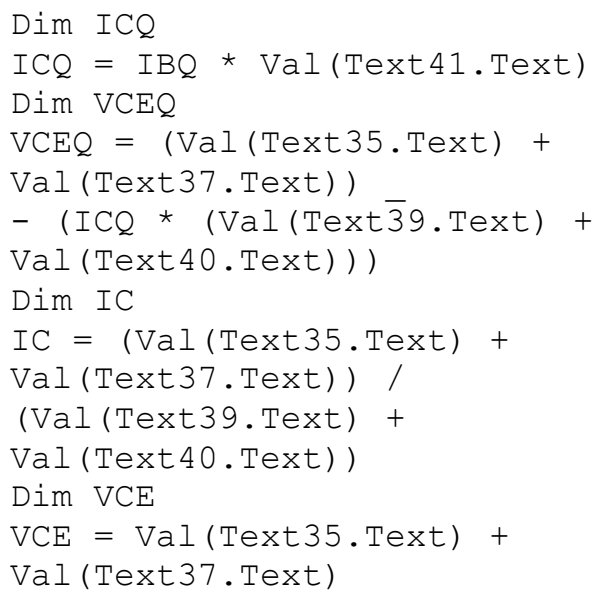

\subsection{Perancangan Laporan (Report)}

Laporan (Report) digunakan untuk menampilkan hasil perhitungan dan memungkinkan proses pencetakannya.

Perancangan laporan menggunakan Crystal Report 8.5 yang meliputi tiga tahap:

\section{a. Koneksi ke Basis Data}

Basis data yang akan digunakan dalam laporan dipilih melalui Data Explorer. Basis data tersebut berasal dari Microsoft Access 2007 dan berisi empat tabel parameter rangkaian pembiasan.

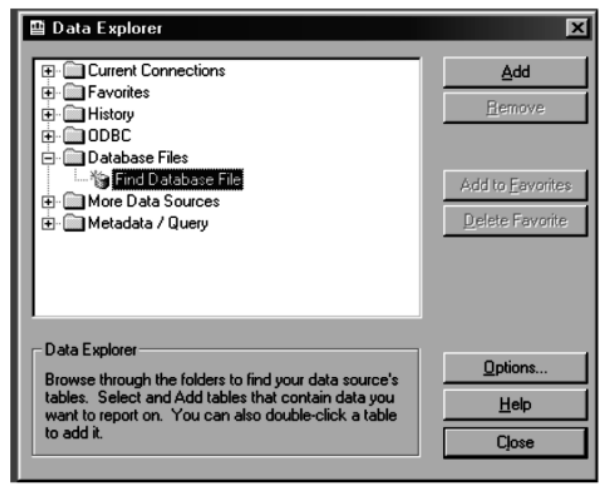

Gambar 22. Data Explorer

\section{b. Pemilihan Field}

Field yang akan ditampilkan dalam laporan diambil dari tabel pada basis data, berupa Field Objects yang dimasukkan melalui Fields Explorer. 


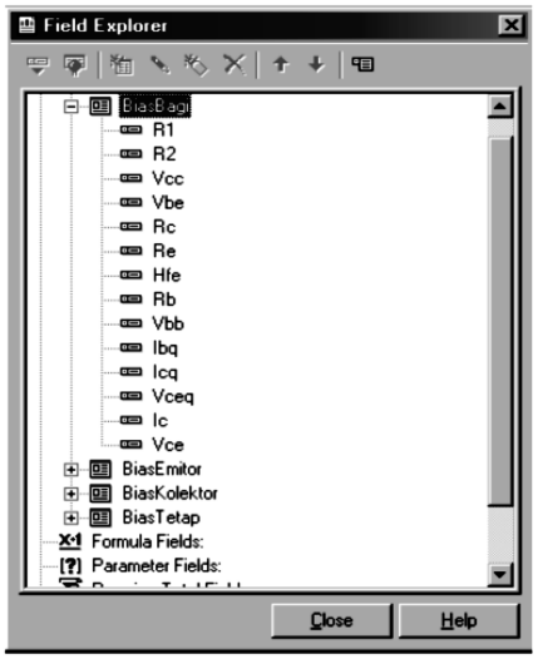

Gambar 23. Field Explorer

\section{c. Pembuatan Tata Letak (Layout)}

Tata letak laporan untuk setiap hasil perhitungan rangkaian pembiasan dirancang sebagaimana pada gambar 24 .

\subsection{Kompilasi}

Proses kompilasi dilakukan melalui Visual Basic 6 untuk mengubah file project menjadi aplikasi setup dalam bentuk executable (EXE).

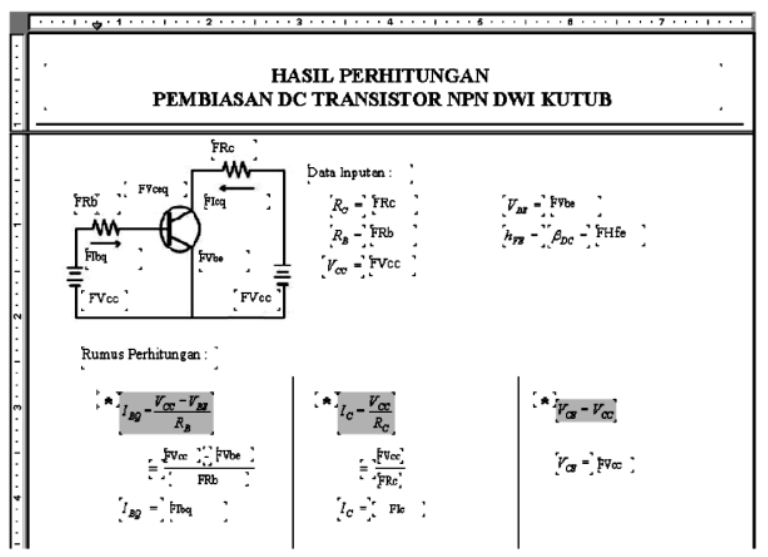

Gambar 24. Rancangan Tata Letak

\subsection{Pengujian dan Debugging}

Pengujian dilakukan untuk melokalisir kesalahan (bug) dalam pemrograman, memperbaikinya (debugging) dan melakukan kompilasi ulang melalui Visual Basic 6.

\section{PENGUJIAN DAN}

PEMBAHASAN HASIL

\subsection{Pengujian}

\section{Perhitungan}

Proses pengujian dilakukan dengan membandingkan persentase kesalahan antara hasil perhitungan manual dengan hasil penggunaan aplikasi untuk keempat jenis rangkaian pembiasan.

Persentase kesalahan (Percent Error) kemudian dihitung melalui rumusan berikut:

$$
\delta=\left|\frac{v-v_{\text {approx }}}{v}\right| \times 100
$$

dengan:

$\delta \quad=$ persentase kesalahan $(\%)$

$v \quad=$ nilai hasil perhitungan manual

$v_{\text {approx }}=$ nilai hasil pengukuran

Perhitungan dilakukan melalui sebuah skenario dengan nilai-nilai parameter tertentu yang sudah diketahui sebelumnya.

Adapun proses perhitungan secara manual dilakukan dengan bantuan kalkulator menurut rumus-rumus pembiasan transistor sebagaimana pembahasan teori.

\subsubsection{Hasil Uji Perhitungan Bias Basis}

Perhitungan dilakukan untuk mengetahui nilai-nilai pada titik operasi ( $\mathrm{I}_{\mathrm{BQ}}, \mathrm{I}_{\mathrm{CQ}}$ dan $\mathrm{V}_{\mathrm{CEQ}}$ ) dan nilai-nilai maksimum pada garis beban yaitu $\mathrm{I}_{\mathrm{C}(\max )}$ dan $\mathrm{V}_{\mathrm{CE}(\max )}$.

Parameter-parameter yang sudah diketahui: $\mathrm{h}_{\mathrm{FE}}=150 ; \mathrm{V}_{\mathrm{CC}}=15$ Volt; $\mathrm{R}_{\mathrm{B}}=100$ $\mathrm{K} \Omega, \mathrm{V}_{\mathrm{BE}}=0.7$ (Silicon), $\mathrm{R}_{\mathrm{C}}=200 \Omega$

Berikut ini tampilan hasil perhitungan aplikasi dan gambar rangkaian: 


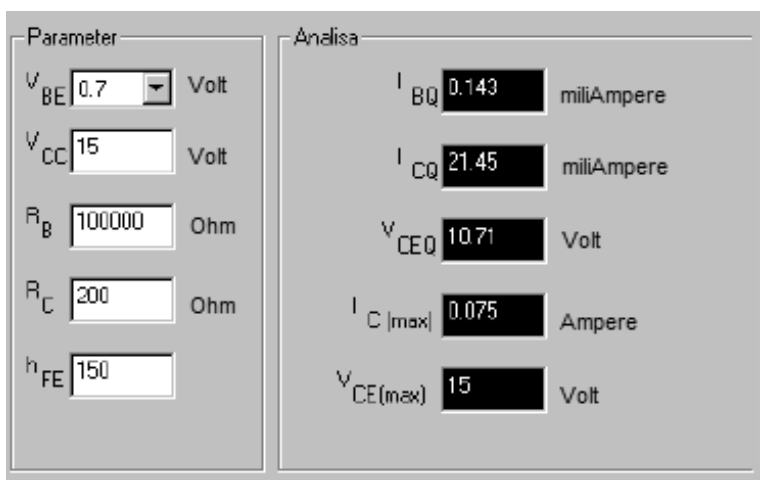

Gambar 25. Hasil Perhitungan Aplikasi untuk Bias Basis.

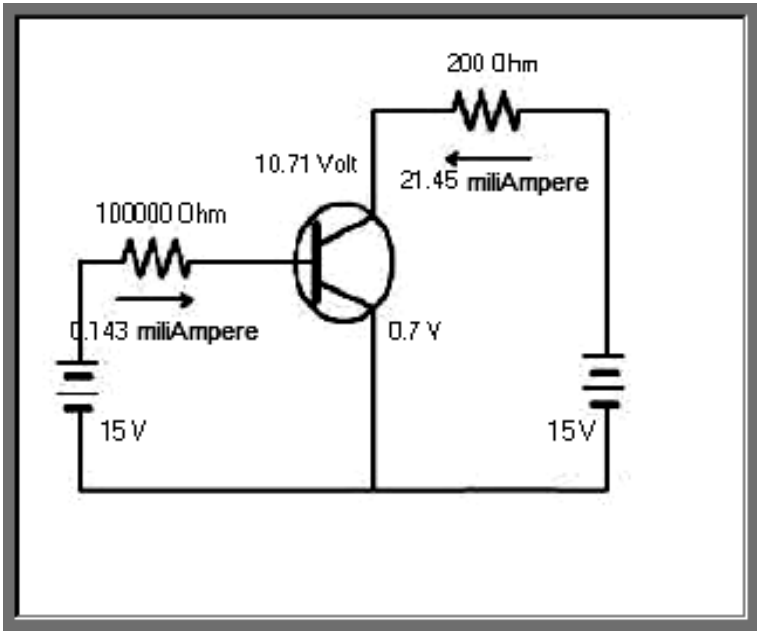

Gambar 26. Tampilan Rangkaian Bias Basis

Persentase kesalahan perhitungan untuk rangkaian ini adalah sebagai berikut:

Tabel 2. Persentase Kesalahan Perhitungan Bias Basis.

\begin{tabular}{cccccc}
\hline \multirow{2}{*}{ No. } & $\begin{array}{c}\text { Para- } \\
\text { meter }\end{array}$ & Satuan & \multicolumn{2}{c}{ Hasil Perhitungan } & Error \\
\cline { 4 - 5 } & $\mathrm{I}_{\mathrm{BQ}}$ & $\mathrm{mA}$ & 0.143 & 0.143 & 0 \\
\hline 1 & $\mathrm{I}_{\mathrm{CQ}}$ & $\mathrm{mA}$ & 21.45 & 21.45 & 0 \\
2 & $\mathrm{Nanual}$ & Aplikasi & $(\%)$ \\
3 & $\mathrm{~V}_{\mathrm{CEQ}}$ & Volt & 10.71 & 10.71 & 0 \\
4 & $\mathrm{I}_{\mathrm{C}(\max )}$ & $\mathrm{mA}$ & 75 & 75 & 0 \\
5 & $\mathrm{~V}_{\mathrm{CE}(\max )}$ & Volt & 15 & 15 & 0 \\
\hline
\end{tabular}

\subsubsection{Hasil Uji Perhitungan Bias Bagi Tegangan}

Perhitungan dilakukan untuk mengetahui nilai-nilai pada titik operasi ( $\mathrm{I}_{\mathrm{BQ}}, \mathrm{I}_{\mathrm{CQ}}$ dan $\mathrm{V}_{\mathrm{CEQ}}$ ), nilai-nilai ekuivalen Thevenin $\left(\mathrm{R}_{\mathrm{B}}\right.$ dan $\left.\mathrm{V}_{\mathrm{BB}}\right)$ dan nilai-nilai maksimum pada garis beban yaitu $\mathrm{I}_{\mathrm{C}(\max )}$ dan $\mathrm{V}_{\mathrm{CE}(\max )}$.

Parameter-parameter yang sudah diketahui: $h_{\mathrm{FE}}=100 ; \mathrm{V}_{\mathrm{CC}}=20$ Volt; $\mathrm{R}_{1}=20$ $\mathrm{K} \Omega, \mathrm{R}_{2}=30 \mathrm{~K} \Omega, \mathrm{V}_{\mathrm{BE}}=0.7$ (Silicon), $\mathrm{R}_{\mathrm{C}}=2$ $\mathrm{K} \Omega, \mathrm{R}_{\mathrm{E}}=3 \mathrm{~K} \Omega$

Hasil perhitungan aplikasi dan gambar rangkaian adalah seperti pada gambar 27 dan 28.

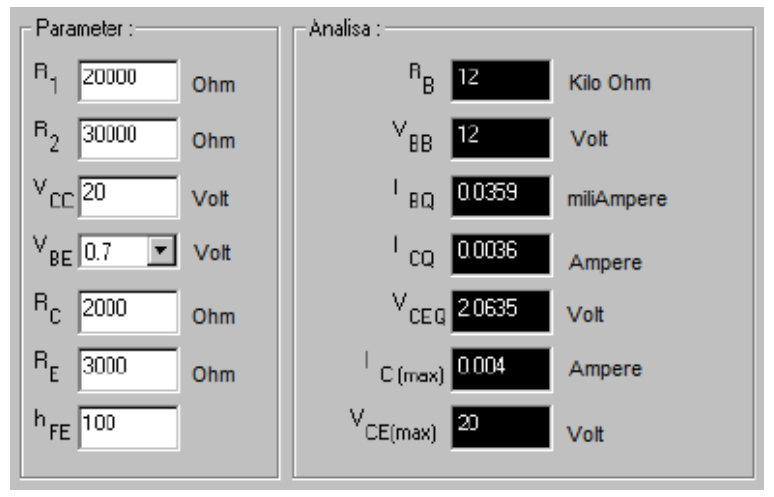

Gambar 27. Hasil Perhitungan Aplikasi untuk Bias Bagi Tegangan.

Persentase kesalahan perhitungan untuk rangkaian ini seperti dalam tabel 3.

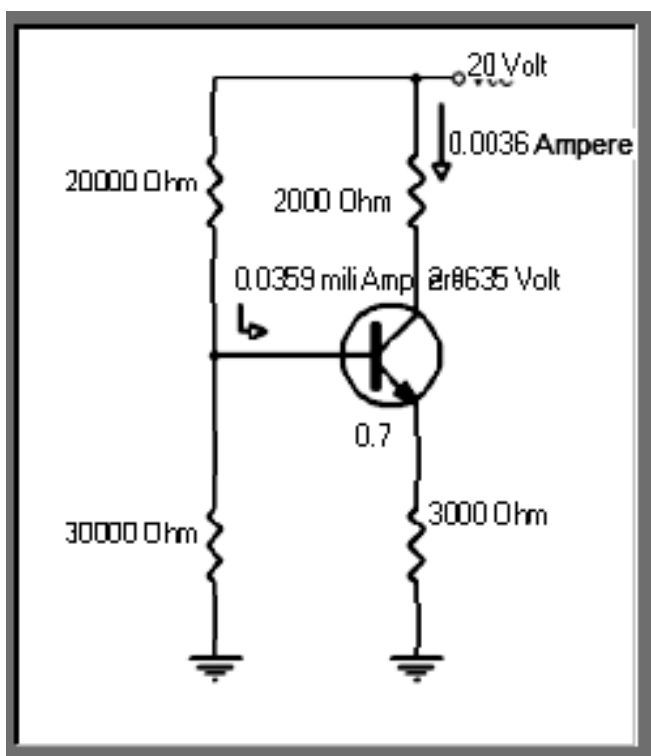

Gambar 28. Tampilan Rangkaian Bias Bagi Tegangan 
Tabel 3. Persentase Kesalahan Perhitungan Bias Bagi Tegangan

\begin{tabular}{|c|c|c|c|c|c|}
\hline \multirow{2}{*}{ No. } & \multirow{2}{*}{$\begin{array}{l}\text { Para- } \\
\text { meter }\end{array}$} & \multirow{2}{*}{ Satuan } & \multicolumn{2}{|c|}{ Hasil Perhitungan } & \multirow{2}{*}{$\begin{array}{c}\text { Error } \\
(\%)\end{array}$} \\
\hline & & & Manual & Aplikasi & \\
\hline 1 & $\mathrm{R}_{\mathrm{B}}$ & $\mathrm{K} \Omega$ & 12 & 12 & 0 \\
\hline 2 & $V_{B B}$ & Volt & 12 & 12 & 0 \\
\hline 3 & $\mathrm{I}_{\mathrm{BQ}}$ & $\mathrm{mA}$ & 0.0359 & 0.0359 & 0 \\
\hline 4 & $I_{C Q}$ & $\mathrm{~mA}$ & 3.59 & 3.6 & 0.28 \\
\hline 5 & $\mathrm{~V}_{\mathrm{CEQ}}$ & Volt & 2.05 & 2.0635 & 0.66 \\
\hline 6 & $I_{C(\max )}$ & $\mathrm{mA}$ & 4 & 4 & 0 \\
\hline 7 & $V_{C E(\max )}$ & Volt & 20 & 20 & 0 \\
\hline
\end{tabular}

\subsubsection{Hasil Uji Perhitungan Bias Kolektor}

Perhitungan dilakukan untuk mengetahui nilai-nilai pada titik operasi $\left(\mathrm{I}_{\mathrm{BQ}}, \mathrm{I}_{\mathrm{CQ}}\right.$ dan $\left.\mathrm{V}_{\mathrm{CEQ}}\right)$ dan nilai-nilai maksimum pada garis beban yaitu $\mathrm{I}_{\mathrm{C}(\max )}$ dan $\mathrm{V}_{\mathrm{CE}(\max )}$.

Parameter-parameter yang sudah diketahui: $\mathrm{h}_{\mathrm{FE}}=120 ; \mathrm{V}_{\mathrm{CC}}=10$ Volt; $\mathrm{R}_{\mathrm{B}}=400$ $\mathrm{K} \Omega, \mathrm{V}_{\mathrm{BE}}=0.7$ (Silicon), $\mathrm{R}_{\mathrm{C}}=4 \mathrm{~K} \Omega$.

Berikut ini tampilan hasil perhitungan aplikasi dan gambar rangkaian:

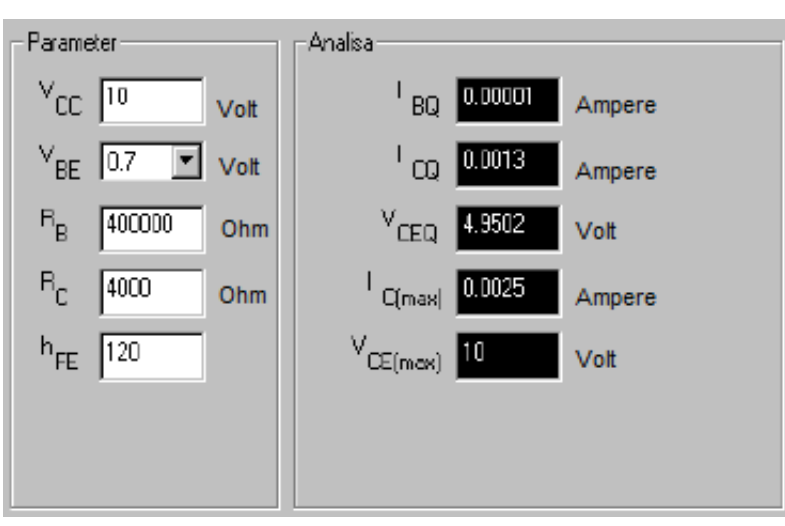

Gambar 29. Hasil Perhitungan Aplikasi untuk Bias Kolektor

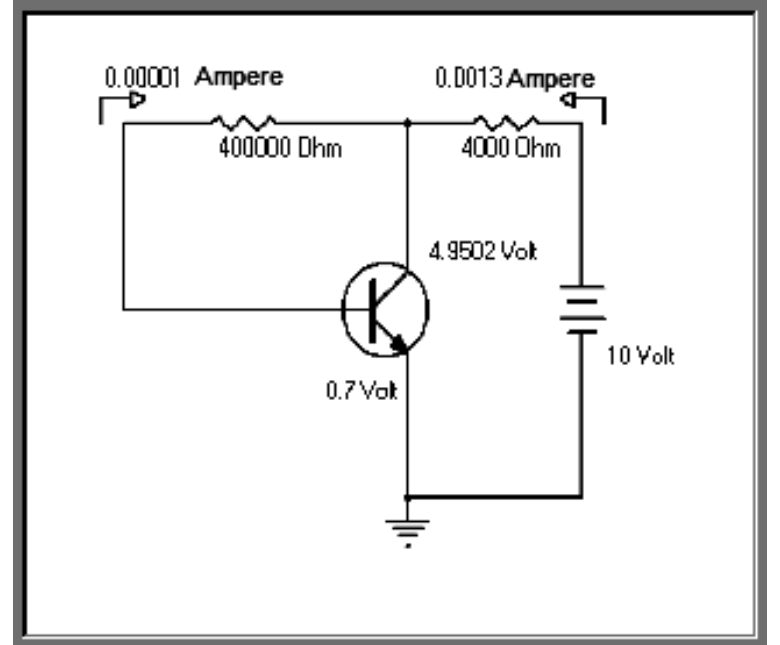

Gambar 30. Tampilan Rangkaian Bias Kolektor

Persentase kesalahan perhitungan untuk rangkaian ini adalah sebagai berikut:

Tabel 4. Persentase Kesalahan Perhitungan Bias Kolektor

\begin{tabular}{cccccc}
\hline \multirow{2}{*}{ No. } & $\begin{array}{c}\text { Para- } \\
\text { meter }\end{array}$ & Satuan & \multicolumn{2}{c}{ Hasil Perhitungan } & Error \\
\cline { 4 - 5 } & & Manual & Aplikasi & $(\%)$ \\
\hline 1 & $\mathrm{I}_{\mathrm{BQ}}$ & $\mathrm{mA}$ & 0.0105 & 0.01 & 4.76 \\
2 & $\mathrm{I}_{\mathrm{CQ}}$ & $\mathrm{mA}$ & 1.26 & 1.3 & 3.17 \\
3 & $\mathrm{~V}_{\mathrm{CEQ}}$ & Volt & 4.96 & 4.9502 & 0.2 \\
4 & $\mathrm{I}_{\mathrm{C}(\max )}$ & $\mathrm{mA}$ & 2.5 & 2.5 & 0 \\
5 & $\mathrm{~V}_{\mathrm{CE}(\max )}$ & Volt & 10 & 10 & 0 \\
\hline
\end{tabular}

\subsubsection{Hasil Uji Perhitungan Bias Emitter}

Perhitungan dilakukan untuk mengetahui nilai-nilai pada titik operasi ( $\mathrm{I}_{\mathrm{BQ}}, \mathrm{I}_{\mathrm{CQ}}$ dan $\mathrm{V}_{\mathrm{CEQ}}$ ) dan nilai-nilai maksimum pada garis beban yaitu $\mathrm{I}_{\mathrm{C}(\max )}$ dan $\mathrm{V}_{\mathrm{CE}(\max )}$.

Parameter-parameter yang sudah diketahui: $\mathrm{h}_{\mathrm{FE}}=150 ; \mathrm{V}_{\mathrm{CC}}=15$ Volt; $\mathrm{V}_{\mathrm{EE}}=12$ Volt; $\mathrm{R}_{\mathrm{B}}=\mathrm{R}_{\mathrm{E}}=20 \mathrm{~K} \Omega, \mathrm{V}_{\mathrm{BE}}=0.7$ (Silicon), $\mathrm{R}_{\mathrm{C}}$ $=10 \mathrm{~K} \Omega$.

Tampilan hasil perhitungan aplikasi dan gambar rangkaian adalah sebagaimana dalam gambar 31 dan 32 . 


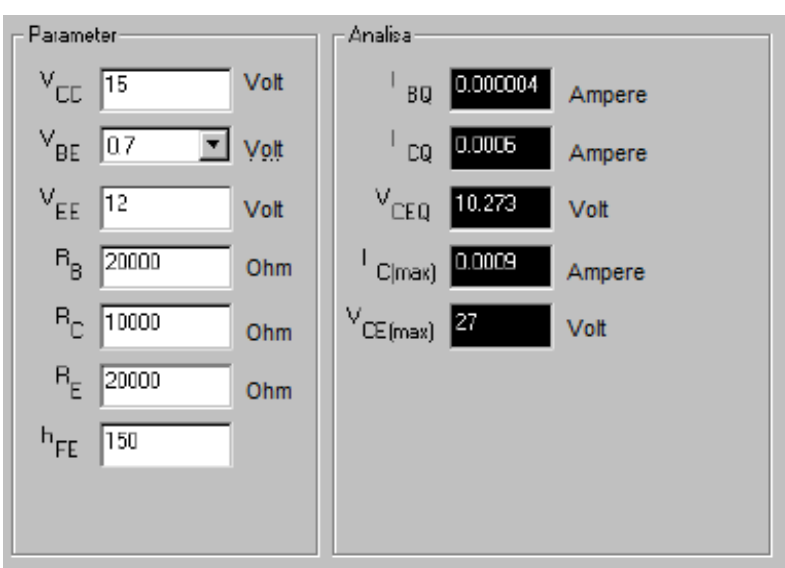

Gambar 31. Hasil Perhitungan Aplikasi untuk Bias Emitter

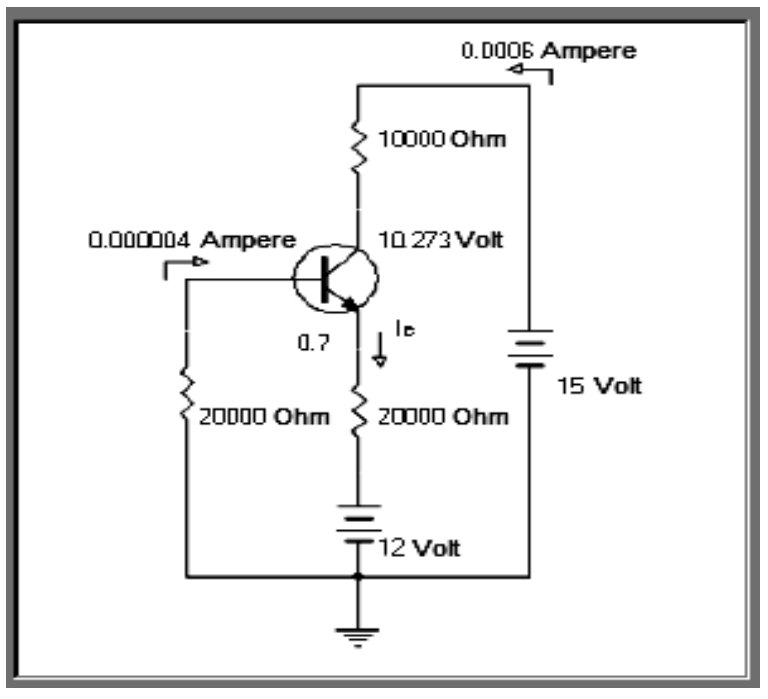

Gambar 32. Tampilan Rangkaian Bias Emitter

Berikut ini persentase kesalahan perhitungan untuk rangkaian bias emitter:

Tabel 5. Persentase Kesalahan Perhitungan Bias Emitter

\begin{tabular}{cccccc}
\hline No. & $\begin{array}{c}\text { Para- } \\
\text { meter }\end{array}$ & Satuan & \multicolumn{2}{c}{ Hasil Perhitungan } & Error \\
\cline { 4 - 5 } & & Manual & Aplikasi & $(\%)$ \\
\hline 1 & $\mathrm{I}_{\mathrm{BQ}}$ & $\mathrm{mA}$ & 0.037 & 0.04 & 8.11 \\
2 & $\mathrm{I}_{\mathrm{CQ}}$ & $\mathrm{mA}$ & 0.555 & 0.6 & 8.11 \\
3 & $\mathrm{~V}_{\mathrm{CEQ}}$ & $\mathrm{Volt}$ & 10.35 & 10.273 & 0.74 \\
4 & $\mathrm{I}_{\mathrm{C}(\max )}$ & $\mathrm{mA}$ & 0.9 & 0.9 & 0 \\
5 & $\mathrm{~V}_{\mathrm{CE}(\max )}$ & Volt & 27 & 27 & 0 \\
\hline
\end{tabular}

\subsection{Pembahasan Hasil}

Dari pengujian tersebut terlihat bahwa untuk kuantitas yang bernilai kecil (yaitu arus) terdapat tingkat kesalahan yang relatif besar. Kesalahan yang terjadi juga dipengaruhi oleh pembulatan (rounding) atau pemangkasan (truncating) selama proses perhitungan. Rata-rata persentase kesalahan keseluruhan dari seluruh parameter perhitungan dalam empat rangkaian pembiasan tersebut adalah $1,18 \%$ atau dengan kata lain aplikasi ini layak digunakan.

Hasil perhitungan yang ada juga dikaitkan dengan bentuk rangkaian sehingga dapat memberikan gambaran keterkaitan antar parameter yang dihitung.

Di sisi lain, menu bantuan (help menu) masih kurang memadai dan penggunaan satuan (Ampere, Volt, Ohm) beserta faktor pengali (mili, kilo, mega dan semacamnya) bersifat kurang fleksibel karena tidak dapat diatur oleh pengguna.

\section{KESIMPULAN}

Berdasarkan perancangan perangkat lunak dan data-data yang diperoleh dari hasil pengujian maka dapat disimpulkan:

1. Pembuatan perangkat lunak perhitungan pembiasan DC pada transistor dwi kutub meliputi tahapan perancangan basis data, perancangan form, pembuatan kode sumber, perancangan laporan, kompilasi dan pengujian serta debugging.

2. Aplikasi dapat melakukan perhitungan dengan tingkat kesalahan yang rendah, sebesar $1,18 \%$

3. Selain melakukan perhitungan, aplikasi dapat menampilkan bentuk rangkaian (beserta seluruh nilai komponen) dan mencetak hasil perhitungan dalam bentuk laporan. 


\section{DAFTAR PUSTAKA}

1. Andersen, Virginia. 2007. Microsoft Office Access 2007: The Complete Reference. McGraw Hill Osborne Media.

2. Boylestad, Robert. Nashelsky, Louis. 1998. Electronic Devices and Circuit Theory (Seventh Edition). Prentice Hall.

3. Floyd, Thomas L. 2005. Electronic Devices, Conventional Current Version, International Edition. Pearson Prentice Hall.

4. Groh, Michael R. Stockman, Joseph C. Powell, Gavin. Prague, Cary N. Irwin, Michael R. Reardon, Jennifer. 2007. Access 2007 Bible. Wiley.

5. Himpe, Vincent. 2002. Visual Basic for Electronics Engineering Applications. Vincent Himpe (Public Domain).

6. Holzner, Steven. 1998. Visual Basic 6 Black Book. The Coriolis Group.

7. Miller, Wilhelm. Robbins, Allan H. 2003. Circuit Analysis: Theory and Practice. Third Edition. Thomson Delmar Learning. Jakarta.

8. Peck, George. 2001. Crystal Reports 8.5: The Comprete Reference. McGraw Hill Osborne Media.

9. Perry, Greg. 1999. Sam's Teach Yourself Visual Basic 6 in 21 Days, Professional Reference Edition. MacMillan Computer Publishing.

10. Siler, Brien. Spotts, Jeff. 1998. Special Edition Using Visual Basic 6. Que. 